\title{
Learning Media based on ICT for Learning Strategy of Accounting Program in Vocational School
}

\author{
$1^{\text {st }}$ Betanika Nila Nirbita \\ The Faculty of Teacher Training and \\ Education \\ Sebelas Maret University, \\ Jl. Ir. Sutami No. 36 A Kentingan \\ Surakarta, Indonesia \\ e-mail: nbetanika@gmail.com
}

\author{
$2^{\text {nd }}$ Soetarno Joy oatmojo \\ The Faculty of Teacher Training and \\ Education \\ Sebelas Maret University, \\ Jl. Ir. Sutami No. 36 A Kentingan \\ Surakarta, Indonesia
}

\author{
$3^{\text {rd }}$ Sudiy anto \\ The Faculty of Teacher Training and \\ Education \\ Sebelas Maret University, \\ Jl. Ir. Sutami No. 36 A Kentingan \\ Surakarta, Indonesia
}

\begin{abstract}
Learning media based on ICT is one of learning media which is very interesting and able to improve motivaton student for learning. This paper is written for the purpose of exploring in details about the needs of learning media based on ICT in vocational school. Nowadays almost every people know about computer or ICT. Students are not capable of understanding the learning material easily without appropriate learning media. Teacher needs develop the learning media based on technology, thus the student can easily to understand about the transaction in service firm in the classroom to improve their competency. The population of this study was all ten grade students of accounting. The sample of this study used a simple random sampling technique to obtain 71 samples. This study is descriptive quantitative research with survey technique. The result of the research shows that $\mathbf{5 6 \%}$ students said difficult to understand accounting lesson, $72 \%$ students boring with the lesson, $48 \%$ said that the media used by the teacher is appropriate enough but still need to be developed, $99 \%$ agree about the development of learning media based on ICT for learning, and $97 \%$ of the students agree about the learning media development in accounting subject to enhance their understanding of knowledge.
\end{abstract}

Keywords: ICT, media, vocational school

\section{INTRODUCTION}

The development of technology provides a great impact on some sectors of life. The development of a more advanced technology is making some sectors are required to be more developed along with the development of technology and one of them is in the education sector. In the education sector, education is required to be able to take advantage of the development of technology with both as part of the effort to improve education because with advanced education will affect the progress of the nation. Therefore education played a big part to increase the quality of the nation. Attention to the world of education in the use of technology for the purpose of education is very important because without special attention isn't it will not grow as technology development which should be used for maximum. One of the ways to take advantage of technology development in the world of education is on the learning that was carried out by educators.

Learning is the most important component in education. The success of learning is determined by the students are able to understand the learning delivered by educators. And the students are required to be active and independent in the learning process. Learning requires active interaction between the teachers and students who will make the learning can be achieved by pc. The current learning requires the students to be active and independent so that will be formed and learning concentrated on students or student center learning. To support this so teachers are required to use the right method of learning and the method can be supported by learning media in the process of delivering the material to the students. The teaching will be deemed more effective when teachers and students using this method and learning media that adequate.

The Media used to support the learning must be able to grow the motivation in students. Media used to clarify the message that will be delivered, invigorate and spirit of the students so that the students are motivated in the learning process and also makes it easier to students in receiving the learning delivered. One of the transfers of information to the students is by using the technology. The use of this technology allowed for teaching and learning activities as other sources are required to support the learning activities in the classroom. Teachers are required to be able to follow the development of technology as one of the supporting learning activities that one can be implemented on a 
learning media. Examples of media that can be used by a educators or teachers including computer-based media, media audio and visual media graphics, media presentation, media photos, media projector and internet-based media. Each of these media has the advantages and disadvantages of each one destined. Teachers are expected to be able to use the media in the teaching and learning process that could certainly make enthusiastic students increased and the students are motivated to follow the teaching and learning process in the classroom and make the students actively in the learning process.

One of the media that is able to attract students and gives the students motivation to learn is that the media was based on the computer. Keller says that used technology can make increase students' motivation to learn and motivaton to learn is important for make students understand the material [1]. The media has been based on this computer can be used as a material for the practice and practice questions for the tutorial to games and for simulations. Using the media computer in the learning activities have some advantages namely with learning media computer then concepts or complex material can be explained with simple so that the students are easy to understand the matter. In addition to the existence of games or games using the computer and psychomotoric aspects students can also develop. The creation of the game of education has been proven as a learning exercise and useful for the students to increase their creativity and development [2]. Using the media based on this computer is liked most because the teachers can see directly emphasize student and enthusiastic students. The motivation learners on the teaching and learning process that uses a computer-based media can be increased and with this motivation the results of the study will increase.

The use of learning through the computer gives the form is good for the development of education and make the computer as a media that is unique to education [3]. The same thing with the research written by Nielsen [4] who proposed that indeed the use of the computer for education is not easy but this is a way to know the impact of the real changes from one of the students. A teacher must change the way of teaching by using media computer. Media with this computer create another impact in the long term which has a real impact on the students and not only a limited shallow knowledge in a learning context. The motivation learners on the teaching and learning process that uses a computer-based media can be increased and with this when the motivation up then the results of the study will increase.

The observation and interview conducted by the students of class $X$ majoring in accounting at SMK, students less understand the given materials. The implementation of learning media that is given by the teacher during this also only in the form of the blackboard and modules without using the LCD already exists. During the teaching and learning activities that are taking place any more charged with independently by the students learn the material that is in the module when the module does not contain the concept that clearly so that when the students are given a different question on the module with the same concept students will feel confusion.

\section{METHODS}

The population of this study was all tenth grade students of accounting. The sample of this study used a simple random sampling technique to obtain 71 samples. This study is descriptive quantitative research with survey technique. In this study, the author determines the needs of learning media based on ICT in the form of interactive multimedia accounting to enhance students' ability to understand the learning materials.

\section{RESULTS AND DISCUSSION}

From interviews with teachers of accounting subjects, the teacher says that teacher used moduls to teach the student and just sometimes used a computer to teach. But a lot of students can't understand with the learning because teachers often only make students to learn individually by using the module and only a brief explanation is given to the students without a pleasant media As revealed by Kim that students can't understand theories and concepts clearly if the technology approach to practice in learning is lacking [5]. And it is very necessary that the learning media can be used for student practice, so students do not get bored to learn about the transaction in service firm in accounting. Because learning media is intermediate between students and learning[6].

The results of the preliminary survey indicate that the students of tenth grade accounting in SMK Negeri 1 Banyudono still find it difficult to understand the basic of bank materials. Of the 71 students representing the X AK $1, \mathrm{X} \mathrm{AK} 2$ two classes, 41 students $(58 \%)$ stated that the basic of bank material is difficult to understand because the teacher just tells the student to learn by moduls a teacher just give some information to carry out their task. (Fig 1). 
Figure 1.

Is the subject of firms service in accounting difficult to understand?

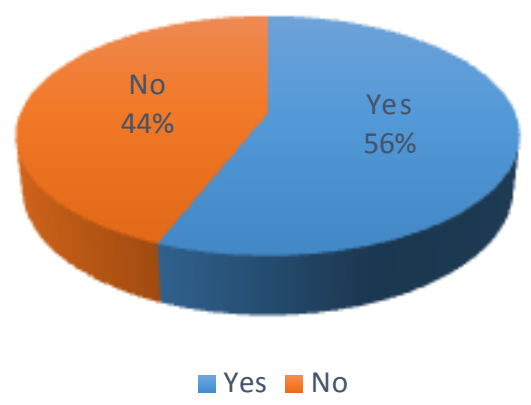

From the results of preliminary observation is known that one of the subjects that are considered difficult to be understood by students is the subject of firm service accounting. In terms of instructional media used by teachers, it has been combined only to be limited to theoretical learning in the classroom. Then viewed from the facet of the learning method in the discussion is quite interesting for students, but the students more often find their own information through the internet, then they feel worried about the material that does not match what will come out during the test. Students feel difficult about the material because the student just learns in the class and read the moduls. And also student fell boring with that learning. (Fig 2)

Fig 2.

Are students getting bored with the lesson?

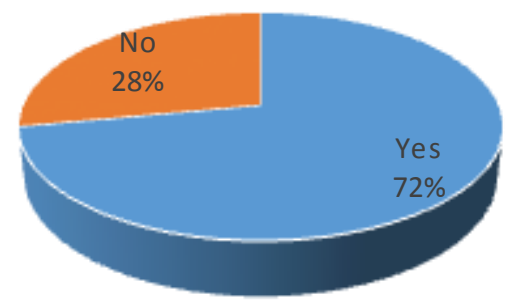

- Yes $=$ No

Students feel bored because of the learning just with moduls and whiteboard. The students agree about the learning media development firms service accounting subject to enhance their understanding. Teachers or educators who teach with creative ideas are able to develop a quality education and are able to create a more meaningful learning and able to open a way that will make learning enjoyable [4]. With creativity from the teacher, the students can understand the materials. From the results of preliminary observation $52 \%$ students say that's the learning media is appropriate but still to develop. The appropriate learning media will make the learning meaningful and successfully. (Fig 3)

Fig 3.

Is the learning media of firms service accounting subject is appropriate?

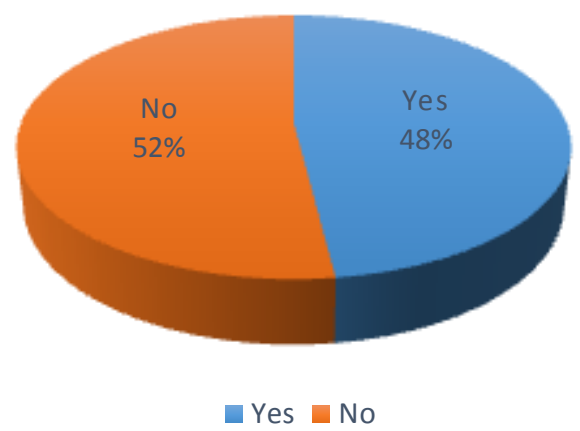

Then the results of student needs analysis showed from 71 students, $99 \%$ students stated the need for the development of learning media for firms service accounting so as not to bored and the material more easily understood. And it can be used for the student because according to from the student, the student can understand easily with this media (Fig 4).

Fig 4.

Do you agree about the development of learning media in firms service accounting subject for learning?

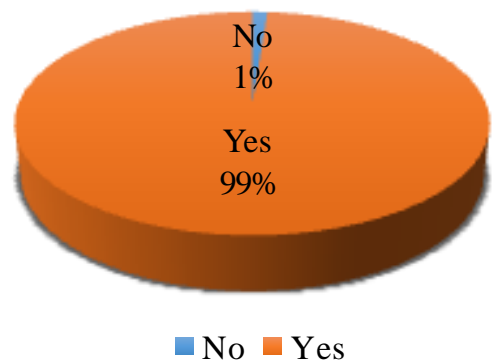

Students say that the learning media can help them to understand the materials in firms service accounting in the class. Because during this lesson they were difficult to understand the materials. Ans student needs learning media that can help them to study this subject. Teaching and learning activities that include group collaboration, task visualization and simulation through laptops and the Internet, hands-on experiments are elements that can enrich students' understanding. And it can improve the quality of learning through the application of technology in the teaching learning process. 
The students said that the development of media for firms service accounting subject is needed (about 96\%). It is important to adopt technology in learning media, thus the students can understand materials easier. If technology is used properly, students can utilize technology as a resource for heightened knowledge and simplified way to achieve a grade. The utilization of technology in firms service accounting subject can make student easier in the lesson and make student easier to understand the materials. So the students agree about the learning media development in firms service accounting subject to enhance their understanding. (Fig 5)

Fig 5.

Do you agree if the learning media is used for increasing understanding with the materials?

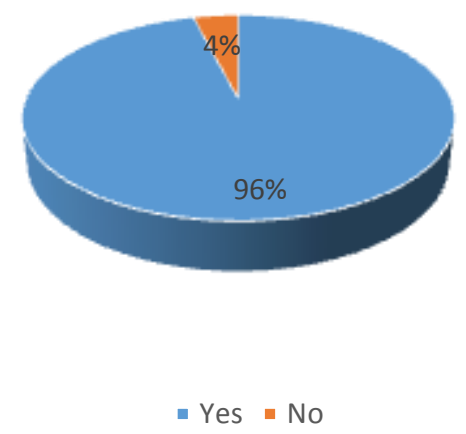

Technology can make a better aducation with use it in the classrom. Althought teacher must learn about the media and it is not easy fot teacher to learn the technology, but it's a must because it can increase the result from the study. The teacher must take a course or seminar to increase the knowledge. Media that can be used $n$ the classroom must be appropriate to the lesson. The teacher must be can to choose the right learning media. ICT is one of the media can be used to ncrease the motivaton, understood, and the learning outcomes. With its prospects, ICT has become an important component of educational reform and an integral part of school curriculum. ICT is considered to be a valuable teaching tool, and the students appear to have the digital competence that is necessary to use ICT. That's why teacher must learn about ICT for a lesson in the classroom.

\section{CONCLUSION}

In this paper, from the survey authors determine the needs of learning media based on ICT for learning in firms service accounting lesson to enhance students' understanding and can improve their knowledge. Students need the learning media can make they not bored so they can follow the learning and can understand the material because in firms service accounting is the basic of accounting that in grade XI and XII students also need that material to next subject. So iits important to the student to understand the materials.

Based on the above description, the author intends to do a research about learning media based on ICT or computer to increased learning outcomes in the future as a solution to the problems found in the learning of firms service accounting.

\section{ACKNOWLEDGMENT}

The author gratefully acknowledges the helpful comments and suggestions of the reviewers, which have improved the presentation.

\section{REFERENCES}

[1] Keller, John. 2016. Motivaton, Learning \& Technology: Applying the ARCS-V Motivation Model. Participatory Educational Research (PER). Vol 3(2), Pp 1-13.

[2] Mercer, T. G., Kythreotis, A. P., Robinson, Z. P., Stolte, T., George, S. M., Haywood, S. K. 2016. The Use of Education to Influence Sustainable Behaviour. International Journal of Sust ainable in Higher Education. Vol 18 No 3, Pp 359-384.

[4] Jayakanthan, R. 2002. Application of Computer Gaames in the Field of Education. The Electronik Library. Vol 20 No 2, Pp 98-102.

[5] Nielsen, Simon E. 2004. Practical Barriers in Using Educational Computer-Games. On the Horizon. Vol 12 No 1, Pp 18-21.

[6] Beetlestone, Florence.2011 . Creative Learning. Bandung: Nusa Media.

[7] Daryanto. 2015. Media Pembelajaran. Bandung: PT. Sarana Tutorial Nurani Sejahtera. 